\author{
Ljupcho S. Risteski (North Macedonia) \\ Institute of Ethnology and Anthropology \\ Faculty of Natural Sciences and Mathematics \\ Ss. Cyril \& Methodius - Skopje \\ E-mail: risteski@ukim.edu.mk
}

\title{
"WE JUST TOOK OUR 'OPINCI' OFF, AND ETHNOLOGISTS WANT \\ US TO PUT THEM BACK ON.” THE STATUS OF ETHNOLOGY IN MACEDONIA IN THE SOCIALIST PERIOD (1946-1953)
}

\begin{abstract}
The text attempts to bring light to significant events connected to the creation and closure of the academic studies in ethnography and ethnology at the Faculty of Philosophy in Skopje in the early socialist period of 1946 to 1953. The analysis includes archived materials from the archives of the Faculty of Philosophy, and the Ministry of Education of the Socialist Republic of Macedonia. Emphasis has been placed on the socio-political conditions during which the studies were begun and shortly after that closed. The paper notes the social and local political and ideological frameworks for living in the socialistic community. Questions connected to the rise and fall of national ethnology in the Socialist Republic of Macedonia are related to ideological frameworks for how socialism's dealt with rural life, royalism, backwardness, traditionalism in contrast to urban employment, communism, progress, and modernity.
\end{abstract}

Keywords: ethnology, folklore studies, Branislav Rusikj, socialism, Macedonia

In Macedonia, one must still wait for the "ideal" conditions for researching the history, which is ethnography, of ethnology and anthropology as academic disciplines. One must keep in mind that such studies have not yet been done, nor has the state shown any interest in financing such research, which would allow understanding of the status of these disciplines during specific periods of crucial social and historical significance in Macedonia - the period between the world wars and the socialist period ${ }^{1}$. It is important to study contemporary sociopolitical conditions in Macedonia and its surroundings to understand the current status of the disciplines. Only a number of publications on the history of the disciplines in Macedonia have been completed (Rusić 1957: 456-59; Konstantinov 1983, 1985, 1988; Palikrusheva: 1997; Risteski: 1997; 2008; Svetieva: 2001,

1 The author of this article has applied with a proposed project to application calls for national scientific-research projects of the Ministry of Education and Culture in RM at least two times (2006 and 2011) with the research aim of the history of ethnology in Macedonia in the socialist period. Not once were the proposals accepted for finance. The last application call by the Ministry was published on 24.2.2011 http://www.mon.gov.mk/index.php/konkursimon/717nip2011. As an applicant to the call, I have not received any formal notification from the Ministry regarding the proposal besides a revision of the text of the call on 14.11.2013. 
2005, 2008). The only progress in this field would be the introduction of the course "History of ethnology in Macedonia" in the study program of Ethnology and Anthropology in 2005.

At first glance, one would think that there is not a lot to do research on and write on in regards to the status of ethnology and anthropology in Macedonia, considering their near-total isolation and marginalization as disciplines. However, systematic ethnographic studies can point to exciting episodes in the history of the disciplines, which must always be taken in an account within the context of the Macedonian social and political milieu and the broader socio-political context of the region.

Following the development of the disciplines in the Socialist Federal Republic of Yugoslavia, under which the Socialist Republic of Macedonia was found, and comparing the state of these disciplines in the region, one can conclude that despite certain similarities, the number of differences was much higher, as these disciplines presented separate national varieties of the socialist social order and strategies of nation-building (Mihailescu, Iliev, and Naumović 2008: 1-2). It is generally understood that "local ethnology and anthropology", despite differences in the formation of the specific socialism, were called national disciplines, and as such participated, in some cases more so than others, in the "construction of nations" ((Mihailescu, Iliev, and Naumović 2008: 2). Thus, "for a long time-period, the nation represented the political context and epistemic framework for acting for all of these 'national ethnology' (Mihailescu, Iliev, and Naumović 2008: 2). It is interesting to examine whether the fragile Macedonian ethnology lost its status and disappeared from the Macedonian public in the early 1950s due to these reasons. Was Macedonian national ethnology too large of a step and serious challenge for the socialist Macedonian society and the creation of the $\mathrm{Yu}-$ goslav spirit of brotherhood and unity? Here, we can also question the extent to which the local Macedonian academic politicized community was part of a socalled courtship of the Yugoslav academic and political apex in fulfilling the socialist ideals.

Consequently, the focus of our research will be to examine the meaning and status of ethnology in Macedonia, as well as to understand the reflections which ethnologists and the discipline of ethnology applied to Macedonian society in the socialist period. In addition to this, we aim to uncover the influences of societal relations on the functioning of this discipline, both in the Macedonian and Yugoslav socialist communities.

\section{Politics and ethnology in Macedonia}

A number of key figures in anthropology, and generally in the social sciences and humanities, such as Clifford Geertz and Eric Wolf in their writings on the development of the disciplines, point to, firstly, that "there are very little things which are authentically autonomous" (Geertz 2002: 2), and that one must approach the history of social anthropology not just as a discipline which spreads its ideas outside of its own boundaries, but as a discipline created under 
the framework of an established socio-political surrounding (Wolf 1999: 121). Hence, one must keep in mind the effect of the social and political climate in the production of anthropological knowledge in Macedonia.

We aim to examine the politics of ethnology in Macedonia, especially in the early socialist period, to understand the status of ethnology in the Macedonian socialist society and to bring light to their mutual influences.

Macedonia entered the socialist Yugoslav state federation as an equal federative unit, which would entail all rights as a state and responsibilities of the functioning of its society. However, the history of the social sciences and humanities in Macedonia did not begin with the creation of the socialist republic. Ethnology was one of the first disciplines established with the University in Skopje in the 1920s, as a pivotal institution in conducting one of the most important national strategies of the Yugoslav state, that is the doing of grand-Serbian national ideas on the territory of Macedonia, at that time called Southern Serbia, and its people Southern Serbs.

In the first years of socialism in Macedonia, as well as in the wider SFRY the intention was to clear away local enemies and opponents of the regime, which existed and were to be found of all profiles. As a result of these aims, the newly formed communist elites, frequently and quite easily labeled individuals, their families and at times whole generations as enemies and "ineligible" for the system at the time, as a result of which they were prevented from completing even the most mundane everyday activities. At that time, communists in Yugoslavia and their ideology were considered to be the only force capable of stopping and rooting out pre-socialist national and religious feelings of the different communities that participated in its creation. As such, issues on ethnicity, national relations, nationalism, and federalism became central political and theoretical problems in the post-war period (Naumovic 2008: 219).

Nevertheless, the new regime clashed with many serious questions related to the survival of its citizens and the new state, in which issues such as the restructuring of the ownership structure and the re-instituting of parts of the prewar industry were included. The most significant change happened in the sphere of state industrialization, which had a crucial role, not only in the economic but in the ideological sense as well. A working-class, the proletariat, was formed, with attempts to eliminate peasantry as one of the dominant societal layers. This led to the abrupt deserting of villages, and unplanned and excessive growth of cities. The peasantry had to be drastically reduced to create a sufficient societal base for the prophesized "socialist state as a state of the working class."

The first years of socialism in SFRY characterized with a firm and rough political and physical control of the events in the country, under the strong influence of the Stalinist regime and the socialist scientific thought of the USSR (Naumovic 2008: 220-221). The naming and defining of the discipline in Yugoslavia as a result of these links is notable. It was named ethnography, based on the global model, and it found its place in academic literature as well as the naming of several institutions, journals, etc. in Yugoslavia and Macedonia. After the breaking of the strong bond and Tito and Yugoslavia's subsequent distancing 
from Stalin and the USSR, a phase began in which one can identify deviations and attempts to redefine terminology in the discipline and institutional names. Nevertheless, reflections on those times are notable in many spheres today.

\section{Peasantry Versus the Working Class, Tradition Versus Modernity}

Historically speaking, most of the population of Southeastern Europe was made up of peasantry (Encyclopedia of Easter Europe, 491-492 с.в. Peasants). The SFRY entered the new socialist social order in 1945, with more than $70 \%$ of its peasant population engaged in the subsistence economy. Thus, one can easily say that they formed the dominant culture of the then-new socialist society. The image of the folk culture of the peasantry generally did not correspond to contemporary ideas and representations of the socialist state of the workers. Peasantry was linked to notions of backwardness, grayness, submissiveness, collectivism, and traditionalism. Even in the political sense, the peasantry in the kingdom of Yugoslavia was generally related to village parties, which were politically connected to nationalism and royalism. Peasant party agrarianism was replaced with nationalism in the late 19th century. Thus, these traditions were part of the highest socialist agenda of intensive transition, in which outdated concepts of peasantry and traditionalism were to be replaced with contemporary ideas, such as the working class and modernism. These concepts were considered to be especially dangerous in the construction of the modern socialist working society in an ideological sense, which is why there was an attempt to, in a way, marginalize them.

It seems that a result of this attitude and ethnology - then considered as a national discipline engaged in the studying traditional cultures of all ethnic and nationalities in the state, studying their ethnogenesis (Rusikj 1948) - was seen as a potential danger for the promotion of specific "traditional" values which by all costs were to be replaced with new ones. Therefore, gradually in the socialist public priority was given to some segments of traditional culture, generally, folklore traditions, traditional songs, and dances, that is, folklore. Dances and music presented by various cultural-artistic ensembles became a substitute for the disappearing culture of the peasantry. Plays created through adapted scenic portrayals were to bring forth officially approved plays on the newly-created nation/nations, its/their cultures, as well as images of "the happy peasantry." On the other hand, the elitist urban society in creation began to serve the socialist patriots adapted forms of "traditional dances," which were supposed to trigger feelings of solidarity among the newly-formed class - the workers (Encyclopedia of Easter Europe, 178-179 с.в. Dance). These developments in the Socialist Republic of Macedonia resulted in the closure of the studies on Ethnology in 1952 and the opening of the Institute of Folklore in 1950. 


\section{Rise and fall of the discipline: Individuals and trends}

The beginnings of ethnology in Macedonia in the period after 1945 must be connected to the creation of institutions of literature and culture.

When speaking of ethnology in Macedonia in the socialist period, one can count the people who dealt with it on two hands. Primarily this is due to the educational politics of socialist Macedonia observed through the general Yugoslav concept, where just several years after the creation of the study group on Ethnography and Ethnology at the Faculty of Philosophy, the same group was soon thereafter closed. Thus, Macedonia was left with the few post-war generations of graduated ethnologists, only a number of which left traces in the discipline to this day. Here we would like to highlight the fact that the ending of the seminar in Ethnology in 1952/53 and the lack of emergence of professionals in the discipline led to Macedonia's lingering in the margins of the disciplines. The lack of educated professionals in the spheres of Ethnology and Anthropology in socialist Macedonia can be felt to this day.

The Faculty of Philosophy in Skopje was created in 1946. The Ethnology group or seminar under the management of professor Branislav Rusikj, the founder of post-war Macedonian ethnology, was formed at the same time. With a letter from one of the highest-ranking politicians in the young Macedonian state, Krste Crvenkovski, he was invited to take part in the establishment of the studies in Ethnology in Skopje. At that time, Rusikj was employed as an assistant in the Department of Ethnology at the University of Belgrade. One could say he enjoyed much better conditions there than those with which he was yet to face following his move to Macedonia. Nevertheless, there were practical reasons Macedonian leaders to invite Rusikj, as well as possible reasons for him to accept the challenge, which most likely cost him much more personal and professional tradeoffs than he initially expected. Rusikj was initially from Macedonia; in fact, his whole family spent most of their lives in Macedonia. Rusikj's family is one of the many families who, during the Balkan wars, faced the suffering and trials of the migrations before the breaking of war. As such, in the period of the Balkan wars, they had to move from their home village of German in Aegean Macedonia to the villages in the Poreche region in the western part of Vardar Macedonia. Branislav Rusikj was born in 1912 in Tomino Selo in Poreche, after which the family of Gjerman Rusikj, Branislav's father, as well as his brothers Vukashin and Svetozar, and Gjerman's second wife, Lenka, moved to Prilep. Gjerman was a wellknown teacher in the city in the inter-war period, while his sons were part of the few young intellectuals educated at the University of Belgrade, and specialized at universities in Europe.

When B. Rusikj began his teaching career in the Ethnology group of the Faculty of Philosophy in Skopje, he faced the new socialist reality in Macedonia and Yugoslavia. That was a time of the mass creation of new proletariat institutions, among which were the Faculties and University in Skopje. New socialist legislation was being created, as well as new operational concepts that were not always following the socialist ideology, and which in time went through drastic 
changes, especially in the first years and the years of the break-in relations between the USSR and SFRY.

The first students in ethnology enrolled in the Ethnology group, a number which was never very high. B. Rusikj was the only professor in Ethnology. From the curriculum of those first years, one can note the active orientation of ethnology as a historical discipline, while beside the two main ethnological subjects which were studied in continuation during the 4-year studies, all other subjects were in the disciplines of history and archeology.

In the period between 1946 and 1951, around 75 students enrolled and studied in the Ethnology study program. In the academic 1952/53, the Ministry of Education, under peculiar conditions, brought forth the decision to end the studies in Ethnology with the explanation that based on the curriculum and the profile of graduates, the studies coincided with studies in the History of Art at the Faculty of Philosophy in Skopje. Based on meager archival information on this crucial period of Macedonian ethnology, one can conclude that essential factors for the bringing of the decision to end the studies had political backgrounds and were influenced by high-ranking officials in Skopje which called upon banal reasons such as primarily the conception of the studies in Ethnology does not produce graduates which are trained enough to join the "operative" (Proceedings of the Board of Higher Education and Science, 4, June 1952, National Archive of Macedonia, 1012.4.7/96), that is, the primary aim of education being to educate as many illiterate citizens as possible, one of the most essential tasks of the Ministry and then political elite at the time, and second, the lack of differentiation of ethnology from other disciplines, especially the history of art. Understandably, these opinions, shared during the meetings of the Board of Higher Education and Science under the Council of Literature, Science and Culture of the Ministry of Education in 1951-52 were brought forth by local politicians in Skopje, who wanting to comply to written requests from Belgrade, attempted to act upon them in the spirit of socialist obedience. On the other hand, the discussion that took place during the meetings of the Board of Higher Education and Science (BHES) is interesting as it was directed towards the issue of whether the study programs at the Faculty of Philosophy should aim to produce graduates to become teachers, that is, operatives who would have to almost solely deal with educating the masses, or whether there should be a focus on scientific work, through which individuals could be trained to continue their professional careers in the sphere of scientific and research work. During the meetings - attendees being representatives of the Faculty, renowned professors such as prof. Dr. Katalinikj Marin, prof. Dr. Miljovski Kiro, prof. Dr. Mirovski Todor, prof. Dr. Atansije Uroshevikj and others - the opinion that the faculties must not lose their scientific character was strongly voiced, strongly alluding to the attempts to shut down the departments of Ethnology and History of Art. The Dean of the Faculty of Philosophy, prof. Dr. Atanasija Uroshevikj, in his presentation during a meeting of the BHES held on June 11, 1952, shared the following: "My thinking, comrades, I have shared with you last meeting. It is my opinion that the Faculty will lose its scientific character should the Ethnology group and the History of Art group be closed. It is a trage- 
dy for Macedonia, which is rich with such ethnological materials, in which a Faculty of Philosophy exists, to not have an Ethnology group. The same goes for the History of Art group. By transferring these subjects to other groups, we would not be producing professionals - scientists - from those two disciplines; rather, people would only have those two subjects. I have defended my position to the Council as well. I believe that the two groups must continue working, with a limited enrollment of students, while they should be staffed as soon as possible with teaching staff. I believe it is wrong for foreigners to analyze ethnological materials from Macedonia or for the People's Republic of Macedonia to not educate such professionals when an Ethnology group, or History of Art group, already exists" (Proceedings from the Meeting of BHES, CLSC of PRM held on June 11, 1952, 1012.4.7/120).

This vital question was long discussed during the meetings of the Council and the Faculty of Philosophy, during which, as can be seen from the Proceedings of the BHES, the Dean of the Faculty, prof. Sr. Atanasija Uroshevikj, shared the Faculty's decisions: "During the meeting of the Council, held on Saturday, the issue [on the closing of the study groups, noted by Lj. R.] was raised and discussed long after. Finally, with a majority, the decision was made not to close the Ethnology and History of Art groups, and on the question of their continuation there were two suggestions: the first suggestion was to limit the number of enrollments of new students in the two groups, and the second was to freeze the enrollment of new students for a number of years. With a majority of votes, the suggestion to limit the enrollment of new students for these two groups was accepted - to five students annually" (Proceedings of the Meeting of BHES, CLSC of PRM held on June 11, 1952, 1012.4.7/119).

Due to the complexity of this question, by the suggestion of prof. Blazhe Koneski at the meeting of the BHES held on June 4, 1952, and a separate Comittee was created which was to examine the facts and suggestions in-depth, determine the positive and negative aspects of the closing of the study group, and afterward to present their proposal in regards to this issue to the Council. Members of the Committee were members of the Board: Blazhe Koneski, Dimche Levkov, and Pencho Ikonomov, as well as the Dean of the Faculty of Philosophy, prof. Dr. Atanasija Uroshevikj (Proceedings of BHES, 4 June 1952, State Archive of Macedonia, 1012.4.7/99).

From the proceedings of the BHES, one can see that the Committee was not capable of completing one holistic proposal; instead, each member presented their personal opinions. From this, we can see that the Committee was not able to reach a consensus regarding the question of the closing or continuation of the two groups at the Faculty of Philosophy. Based on the opinion of prof. Levkov and members of the Council of the Faculty of Philosophy, the following is shared "Firstly, that the Faculty of philosophy were to lose its scientific character to an extent with the closing of the two groups. The second argument was that the Ethnology group is a national group and that the national character must continue to exist in this group [italicized by Lj. R.] ... It was underlined that with the closing of these groups, we take upon ourselves the enormous historical responsibility, 
which is completely unfounded" (Proceedings of the Meeting of the BHES, CLSC, PRM held on June 11, 1952, 1012.4.7/120).

From the presentations of individual members of the Committee, one can note an element of authoritative behavior towards the party leaders, which aimed to close these study groups. The reasons for such attitudes from some members of the Committee must also be related to the seemingly unwarranted obstruction to the work begun by Branislav Rusikj in Skopje. As such, professor Levkov, in continuation of his discussion that the decision to close the study groups would bring with it an enormous historical responsibility he interprets in the following way: "It is then undebatable that it is useful for our professionals to examine cultural heritage, but with the closing of these group it does not mean that we will stop producing such professionals. We would not undermine the field at all, rather we have just created an Institute of Folk Culture. On the other hand, with the Ethnology group being as it is now, it is a question of how much it has answered to the national moment. Following the work of this group, I believe the group has not given the acute accent to this moment. At the Council [of the faculty, it is noted by Lj. R.] one could sense fear among the people - whether they would stay here or not. This is a ridiculous issue, as we are not heading towards the path of closing, rather creating, but if we are closing something, that means we are doing so because it is not as important at this moment. Thus, all claims that "we take up historical responsibility, etc." are just basic statements" (Proceedings of the Meeting of the BHES, CLSC of PRM held on June 11, 1952, 1012.4.7/120-121). Thus, professor Levkov, in the proletariat and socialist spirit, proclaiming the "path of creation" and discarding "historical responsibility" as a basic statement continued to elaborate on the possible closing of the study groups, meanwhile offering a simple solution - which at the time was apparently to the benefit of the centres of Belgrade and Zagreb - claiming that "we could train such professionals .... for example in Belgrade and Zagreb, and the wealth of material would still be analyzed by our professionals" (Proceedings of the Meeting of the BHES, CLSC, PRM held on June 11, 192, 1012.4.7/121). A second, especially important note he highlighted, to the dismay of the two study groups, was the fact that they still did not have a full study program. Besides the fact that he claimed, "we do have such groups where there is only one professor, but the character of those groups and the needs of the graduates is such that we need to proceed differently with them."

Prof. Levkov's attitude towards the study groups in the History of Art and Ethnology is different. He concluded that "Within the group of History of Art we only have comrade Dimche Koco, while in Ethnology - comrade Rusikj. As much effort as they give and despite their goodwill, under such conditions, some unpreparedness must be assumed, which has a negative effect on the general quality (Proceedings of the BHES, CLSC of PRM held on June 11, 1952, 1012.4.7/121). On an official proposal of the Council of the Faculty of Philosophy, prof. Levkov once again shared his contrarian opinions on the topic of limiting enrollment to 5 students. Once again in the spirit of neglecting Macedonian national interests, and in the interest of the so-called economic rationalization of the problem he suggested "I do not know whether the efforts of the professors to hold lectures for 
2-3 students are worth it ... or is it more rational for those two-three to be sent to Belgrade or Zagreb. I believe the second option is more acceptable" (Proceedings of the Meeting of BHES, CLSC of PRM held on June 11, 1952, 1012.4.7/ 121).

The personal discussion of another member of the Committee, Pencho Ikonomov, also supported the closing of the two study groups. After agreeing with the arguments put forth by Levkov, he suggested one more evidence which "is not being taken into account." "The group of History of Art, as it is now, prepares scientists solely. All of the graduates move on to institutions where they deal with scientific work. I do not know the quality of it or how they deal with science when upon enrollment in the Group, there is no selection, and as it is, everyone deals with scientific work. For one to deal with science, I believe that they ought to have a certain quality. The same stands for the Ethnology group. As such, I believe that both groups need to be closed" [italicized by Lj. R.].

Prof. Katalinikj, the member of the BHES, had the opinion that the groups should continue to function under the Faculty of Philosophy "by aligning the number of newly enrolled students with the operative's needs." As an especially vital argument for their persistence, he states the following, "the national moment is being brewed, there is a need for such professionals in museums" (Proceedings of the Meeting of the BHES, CLSC of PRM held on June 11, 1952, 1012.4.7 / 122). Professor Dimche Koco, on the side for the two groups to stay under the Faculty, highlighted that "once a group is closed, it is difficult to re-open it." He especially notes their importance from the "national point of view."

Gojko Sekulovski, member of the BHES, who at the time was an active party official and one of the political creators of the educational policy in Macedonia, later ambassador of the SFRY to Australia, held the clear opinion to close the study group, to some extent even demonstrating an evident antagonism towards the existence and functioning of the Ethnology group. At the meeting, he also openly accused B. Rusikj of his negative attitude towards the national issue and in general, on the whole of PR Macedonia. "Further on, professor Uroshevikj notes that our wealth should not be analyzed by foreign professionals, rather ours. I believe it important to see how many such professionals have come to us and how many of them our groups have aided? I can openly say that the existence of the Ethnology group has had a negative effect up to now," comrade Gojko was speaking of Rusikj's negative attitude towards the national question and PRM, "From there," continued comrade Gojko, "there would be no sense to defend the existence of the Ethnology group. The information I have shared about Rusikj I do not wish to be considered as an argument; instead, I want to point out that the existence of the group has only had a negative effect, rather than positive. What is our use of ethnologists? I believe that Levkov correctly phrased himself with that question. The need for ethnology in our Republic are minimal and will always be that way. Based on my opinion, even in a future perspective [around ten years], we would not need more than 19 ethnologists. As such, that means that the group is not sustainable.

We need to pay attention to this moment - even the students do not respect this group, they undermine it. And those who have graduated work in entirely dif- 
ferent fields, excluding those who have worked in a museum" (Proceedings of the Meeting of the BHES, CLSC of PRM held on June 11, 1952, 1012.4.7/122-123).

In the context of the desired proletariat, youthful attitude, Sekulovski Gojko, alluding to some reactionary and pro-western orientation of the students, calls them "spoiled kids from Skopje" (Proceedings of the Meeting of the BHES, CLSC of PRM held on June 11, 1952, 1012.4.7/123). And he believed that those who wanted to study the disciplines could do that in Belgrade or Zagreb.

Dimche Mire also contributed to the discussion during the meeting of the BHES. He, too, in the spirit of socialist progress and socialist values of proceeding forward rather than behind, believed that the Ethnology group lowered the Faculty's reputation. "We genuinely do need ethnologists; however, that does not mean that we cannot train good ethnologists at the Faculty in Belgrade or Zagreb. In our group, everyone can join, while there we would only send the best, those which we will choose" [italicized by Lj. R.].

Thus, Dimche Mire suggested the following: "The closing of the Ethnology group and the History of Arts group, however the inclusion of the subject History of Arts in the History group ... in regards to Ethnology I suggest we include Ethnology in the Geography Group" (Proceedings of the Meeting of the BHES, CLSC of PRM held on June 11, 1952, 1012.4.7/124).

At the end of the discussion of these issues, the president of the meeting, comrade Slavko Pop Antovski summarized the following, "From the presentations of the majority it leads that the two groups - Ethnology and History of Arts should be closed, with no new students enrolled in the first year, re-orientation of the second-year students, and allowing the 3 rd and 4th year students to finish their studies (Proceedings of the Meeting of the BHES, CLSC of PRM held on June 11, 1952, 1012.4.7/124).

After the closing of the studies in ethnology, but not the studies in the History of Arts, Ethnology was added as a subject to the studies in Geography, and professor Branislav Rusikj was utterly marginalized.

\section{Ethnology and Folklore Studies - Unproductive Competitiveness}

Examining the history of the disciplines in Macedonia and their institutionalization, it seems that the political effects of the new socialist regimes and the communist party were of crucial importance. These effects, as stated above, were clearly visible in regards to the issue of the short-lived existence of the university studies of Ethnology in Macedonia and the political decision to shut them down. Of course, politics versus cultural heritage, traditional culture, and other social aspects of everyday life can be seen in the process of political decision-making on the opening of the Institute of Folklore, today, the Institute of Folklore "Marko Cepenkov" - Skopje.

Towards the end of the 1940 s in Macedonia, there was an attempt to create scientific-research institutions with the aim of professionally, systematically, and holistically studying and protecting ethnological and folklore cultural heritage.

Based on archival materials, one can determine that professor Branislav 
Rusikj, who at the time was the only professor of ethnology in Skopje, was one of the most critical figures included in the process of conceptualizing the structure and scientific competence of the new research institutions. For B. Rusikj it was more than clear that the new research institution must as much as possible be oriented towards the studying of folk culture as the basis for understanding contemporary Macedonian society, the socialist society. From there, he was alluding to the creation of the Institute for the study of folk culture, of the Institute of folk culture, Institute of Macedonian folk culture, Institute of folk culture of PRM, or at least, the Ethnological Institute.

From archival documents related to the creation of several drafts of Handbook of Organization and Work in the new research institute, one can note that, most likely, the adjective 'Macedonian' was removed from the naming of the institution, pointing to the distancing of attempts to give a "national" prefix to the institution. It seems that, in the process of creating a cultural policy in the PRM in early socialism, the aim was to focus the research on the culture, rather than the ethnic, national or other social aspects of living, as in the past and present.

In one of the version of the Handbook of Organization and Work of the Institute of Macedonian folk culture, Article 1 suggests that the institute will base its work "on the territory of the People's Republic of Macedonia and other Republics", alluding to research work within the state boundaries on SFRY and the administrative boundaries of the Yugoslav republics. This position could be interpreted as an attempt to close the issue in regards to future research expeditions of the Institute to neighboring countries in which populations connected to Macedonia live (Handbook...., State Archive of Macedonia, Fund 1370, Ministry of Education, Science and Culture 1951-1951; 1.1370.1.28/123).

Under Article 2, the main aims of the future institute are to elaborate as:

1. "Organizing the work of collecting, systematizing and conserving folklore heritage of the Macedonian nation;

2. Scientific analysis and classification of the collected material from the sphere of folk culture;

3. Provide advice and professional opinions in regards to the application of folk art in handcrafts, music, industry, construction, etc.

4. Collaborating with organizations, associations, and institutions which work in the propagation of our folk culture within the Federative National Republic of Yugoslavia and abroad and to maintain the purity and authenticity of our folk art craft;

5. To care for the maintenance and further development of our folk art craft;

6. To publish scientific and popular-scientific publications in its area of work." (Handbook..., SAM, Fund 1370, MESC 1951-1951; 1.1370.1.28/123)

From the list of primary responsibilities of the Institute, one can note that the focus of its work should be in the sphere of folklore heritage and folk culture, with a specific accent on folk art. In later versions of the Handbook, the term "Macedonian nation" is removed from indent 1, most likely with the aim to withdraw from issues which could cause reactions in the context of the Yugoslav federation and perhaps in Macedonia, with scientific research to be termed as "local" 
or "Yugoslav" and never "national" or "Macedonian" in the spirit of the creation of the contemporary, socialist, Macedonian nation.

It is interesting that it was suggested for a high priority of the new research institution to be its socially acceptable and applicable activities in the sphere of applying traditional values to folk art in contemporary forms of folk and industrial production, even in modern construction.

Six professional departments within the Institute were envisioned:

1. Department of folk architecture

2. Department of folk customs

3. Department of folk literature

4. Department of folk dances and 'oro's

5. Department of folk music

6. Department of folk art, ornament studies, woodcarving, fresco painting, embroidery, etc.

(Handbook..., SAM, Fund 1370, MESC 1951-1951; 1.1370.1.28/126).

Branislav Rusijk was opposed to the idea of the creation of the Institute of Folklore from the very beginning. He believed that by putting an accent on folklore, the scientific and research work of the institution would be significantly limited. Rusikj saw research on folklore as the area of one of the departments which would eventually be opened within an institute with a broader research scope.

In the public debate which began to be held through transcripts of the newsletter of the PRM, and which was not usual during the time of early interventionalist socialist, Rusikj openly held the position that such a research institute should incorporate all aspects of folk culture, in no case placing an accent only on folklore. In fact, in this period in Macedonia, an uncomfortable discussion on the place and role of ethnology and folklore studies was pushed forward, transferred from other Yugoslav regions and directly connected with some ideological and political views of the eventual repercussions that ethnology and folklore studies could have over the development of the contemporary socialist society. It must be openly said that folklore studies were seen as the less "dangerous" in regards to the opening and eventual ignition of some of the burning national and ethnic issues, since it was more-so oriented towards specific segments of folk craft, which can easily be interpreted as heritage, a resource worth preserving and protecting (Risteski 1997: 49-50).

Thus, as a result of the unproductive competition between ethnology and anthropology, the tendency arose to protect folklore studies as the functional equivalent of the former national disciplines, in a milder form. The result of this unproductive competition, in the Macedonian framework, was the creation of the Institute of Folklore, where ethnology was present only in the Department for folk dances and customs. This demonstrates the visible distancing of official Macedonian politics in the period of early socialism from the eventual opening of any issues of national interests for the Republic of Macedonia. As can be seen from the conception of the Institute, all research-based aspects of identity 
were ignored, as was the question on the origin of communities or other issues connected to the majority Macedonian or other minority communities.

Beside the long-lasting discussion and public debates that B. Rusikj, as representative of ethnologists, held in Macedonia in the period from 1950 to 195455 with representatives from the folklore discipline and their political supporters, it seems that he lost the battle in regards to defining the scientific character of the Institute, similarly as with the studies in ethnology.

\section{Conclusion}

By examining the development of ethnology as a discipline in the socialist federation, we can conclude that despite the many similarities in the specifics of the status of ethnology in other republics in the SFRY, it has many more differences, demonstrating its national variants in the socialist social order in SR Macedonia. It is generally accepted that "local ethnology and anthropology", regardless of differences in the formations of the socialism, were termed national disciplines, and as such, more or less participated in the "creation of nations." From there, "the nation was for a long time-period the political context and epistemic framework for behavior for all of this "national ethnology." It is interesting to see whether the fragile Macedonian ethnology lost its status and disappeared from the Macedonian social scene at the beginning of the 1950s due to these reasons. Was the Macedonian national ethnology too big of a step and severe challenge for the socialist society and creation of the Yugoslav dream of brotherhood and unity? Here, we can also raise the question of the extent to which the Macedonian local academic politicized community holds the responsibility of courting the Yugoslav academic and political apex in carrying out the socialist ideals. The first years of socialism in SFYR were characterized by a sharp and rough political and physical control of the events in the country under the strong influence of the Stalinist regime and socialist scientific thought of the USSR. Based on the Soviet model, it was termed as ethnography, which had effects on the academic literature, as well as the naming of some institutions, journals, etc. in Yugoslavia and Macedonia. After the breaking of that strong bond and distancing of Tito and Yugoslavia from Stalin and the USSR, began a phase in which significant distancing was made as were attempts to redefine the terminology of the disciplines and the names of the institutions.

As a result of this attitude and ethnology, then considered to be a national discipline which deals with the study of national culture of all ethnic and national groups in the country, studying the laws of their ethnogenesis (Rusikj 1948) was defined as a potential danger in the promotion of certain "traditional" values which were by all means to be replaced with new ones. As a result of this, gradually, the socialist public began to give priority to specific segments of folk culture, mainly folklore tradition, folk dances and songs, that is, folklore. The dances and music presented by different cultural, artistic ensembles became a substitute for the disappearing culture of the peasantry. Representation created through adapt- 
ed scenic displays were to create officially approved-of plays on the newly created nation/nations, its/their cultures, as well as images of "the happy peasanty."

\section{Sources}

Proceedings from the Board of Higher Education and Sciences (BHES), June 4, 1952, State Archive of Macedonia (SAM), 1012.4.7/96 [Записник на Одбор за високи школи и наука (ОВШН), 4, јуни 1952, Државен Архив на Македонија (ДАМ), 1012.4.7/ 96]

Proceedings from the BHES, Council of Literature Science and Culture (CLSC) of the People's Republic of Macedonia, held on June 11, 1952, SAM, 1012.4.7/120 [Записник од состанокот на ОВШН при Советот за просвета, наука и култура (СПНК) на Народна Република Македонија одржан на 11 јуни 1952, ДАМ, 1012.4.7/ 120)]

Handbook of Organizaiton and Work of the Institute of Macedonian Folk Culture, SAM, Fund 1370, Ministry of Education Science and Culture 1951-1951; SAM, 1.1370.1.28/128 [Правилник за организацијата и работата на Институтот за Македонска народна култура, ДАМ, Фонд 1370, Министерство за просвета, наука и култура 1951-1951; ДАМ, 1.1370.1.28/123]

\section{References}

Константинов, М. 1985. „Етнологијата на Македонија во современиот миг“. Годишен зборник: Географија 29: 201-209. Скопје: Институт за географија, Природно -математички факултет, Универзитет „Кирил и Методиј”.

Константинов, М. 1988. „Постигања на македонската етнологија“, Предавања на XX семинар за македонски јазик и култура на Универзитетот “Кирил и Методиј” (Скопје - Охрид, 7-27 јули 1987). 271-286. Скопје: Универзитет “Кирил и Методиј”. 
Ристески, Љ. С. 1997. Ракописната заоставштина на Бранислав Русиќ. Прилог кон историјата на етнолошката мисла во Македонија. Битола: "Мисирков".

Русиќ, Б. 1954а. Дискусија околу Фолклорниот институт. Нова Македонија XI: 11.

Русиќ, Б. 1954б. Етнографија или етнологија. Зборник Матице Српске, Бр.VIII, Нови Сад, 55-66.

Русиќ, Б. 1955. Едно појаснување (во врска со дискусијата за Фолклорниот институт). Нова Македонија II: 8.

Русиќ, Б. 1957, Bericht über die ethnologisch Arbeit in der VR Mazedonien (19451955). Südost Forschungen XVI: 156-159.

Русиќ, Б. 1959. Odredba pojma folklora. Rad Kongresa Folklorista Jugoslavije u Varaždinu 1957, Savez Folklorista Jugoslavije, pp. 271-273. Zagreb.

Русиќ, Б. б.г. „Етнологијата и нејзината должност во Македонија“. Архив на MAНУ, К-1, AE 61-1-6 (ракопис).

Русиќ, Б. б.г. Антропологија Македоније. Архив на МАНУ, К-1, АЕ 6о, 1-5(ракопис).

Русиќ, Б. б.г. Етнологија. Архив на МАНУ, К-1(ракопис).

Светиева, А. 2001. „Статусот на етнологијата на Универзитетот “Св. Кирил и Методиј” во Скопје“, Реферат претставен на бугарско - македонска конференција: "History and Education”, Sofia, 8-9 June 2001, ракопис.

Светиева, А. 2005. „Конечно Институт за етнологија и антропологија на Универзитетот „Св. Кирил и Методиј“ - Скопје, Природно математички факултет“, Етнолог 11: 225-232, Скопје: Македонско етнолошко друштво.

Encyclopedia of Eastern Europe. 2000. From the Congress of Vienna to the Fall of Communism, Ed. by Richard Frucht (Garland Reference Library of Social Science), Routledge.

Geertz, Clifford. 2002. The Politics of Culture, Asian Identities in a Splintered 
World. Misuzu Shobo.

Konstantinov, M. 1983. 'Etnologija u Makedoniji'. Bo: Zbornik 1 Kongresa jugoslovenskih etnologov in folkloristov 1. 88-94. Ljubljana: Savez udruženja folklorista Jugoslavije.

Mihailescu, V., I. Iliev, and S. Naumović. 2008. Studying Peoples in the People's Democracies: Socialist Era Anthropology in South-East Europe. Berlin: LIT Verlag.

Naumović, S. 2008. 'Brief Encounter, Dangerous Liaisons and Never-ending Stories: The Politics of Serbian Ethnology and Anthropology in the Interesting Times of Yugoslav Socialism'. In: Studying Peoples in the People's Democracies: Socialist Era Anthropology in South-East Europe, Eds. Vintila Mihailesky, Ilia Iliev, Slobodan Naumović. 211-26o. Berlin: LIT Verlag.

Palikruševa, G. 1997. 'The Development of Macedonian Ethnology and Folklore'. Ethnologia Balkanica 1: 214-217.

Risteski, Lj. S. 2004. 'The Achievements of Ethnology in Investigating Folk Religion and Mythology in Macedonia'. In: Ethnology of Religion. 175-190. Budapest: Akademiai Kiado.

Svetieva, A. 2009. 'On Macedonian Ethnology and the work of prof. Gjorgji Zdravev, Ph.D.', Bo: Social and Spiritual Aspects of Material Culture, 1317. Skopje: Institute of Ethnology and Anthropology, Faculty of Natural Sciences and Mathematics, "Ss. Cyril and Methodius" University in Skopje.

Wolf, Eric (with Sydel Silverman). 2001. Pathways of Power: Building an Anthropology of the Modern World. University of California Press. 
EthnoAnthropoZoom 